\title{
STUDY OF VARIATION OF NATURAL INGREDIENTS TURMERIC EXTRACT (CURCUMA DOMESTICA) AND DAYAK ONION (ELEUTHERINE PALMIFOLIA (L.) MERR) ON THE TREATMENT OF INFECTED SANGKURIANG CATFISH (CLARIAS GARIEPINUS) CATFISH AEROMONAS HYDROPHILLA BACTERIA
}

\author{
Akhmad Fakhrizal Nur ${ }^{1}$, Noor Arida Fauzana ${ }^{2}$, Fatmawati ${ }^{2}$ \\ ${ }^{1}$ Postgraduate Fisheries Science Student, Lambung Mangkurat University, Jl. A. Yani km. 36 Banjarbaru, South \\ Kalimantan, Indonesia \\ ${ }^{2}$ Faculty of Fisheries, Lambung Mangkurat University, Jl. A. Yani km. 36 Banjarbaru, South Kalimantan, Indonesia
}

https://doi.org/10.35410/IJAEB.2020.5457

\begin{abstract}
Catfish farming has been popular in every area, but the threat of good diseases caused by parasites, bacteria and viruses continues to threaten every year. One of the deadly and harmful diseases is Motile Aeromonas Septicimia (MAS) which is caused by Aeromonas hydrophilla bacterial infection. Treatment with antibiotics can cause residuals and bacterial resistance to increase, therefore it is necessary to use natural ingredients such as Dayak onion extract and turmeric extract have been effectively used. This study will examine variations in the use of dayak onion extract and turmeric extract used to treat catfish infections due to the attack of Aeromonas hydrophilla bacteria. This study aims to examine the variation of natural ingredients turmeric extract and dayak onion extract on the treatment of sangkuriang catfish infected with Aeromonoas hydrophilla bacteria. Survival in the treatment ranged from $76.67 \%$ to $86.67 \%$, Hematocrit Value at the end of observation 17.0 to 20.67 , leukocrit value at the end of observation 2.67 to 8.67 , value blood plasma at the end of observation 72.33 to 78.33 and hemoglobin values at the end of the observation between 5.33 to 6.27. Treatment of catfish infected with Aeromonas hydrophilla using a variety of natural ingredients turmeric extract (Curcuma domestica) and dayak onion extract (Eleutherine palmifolia) with 25 ppm dayak onion extract and $75 \mathrm{ppm}$ turmeric extract is the best treatment.
\end{abstract}

Keywords: Curcuma domestica, Eleutherine palmifolia, Aeromonas hydrophila, Clarias gariepinus.

\section{INTRODUCTION}

\subsection{Background}

Sangkuriang catfish farming activities are now growing rapidly, along with the large number of consumer demand, so the cultivation of sangkuriang catfish is carried out with intensive cultivation activities, such as high stocking densities and intensive feeding in limited areas. Catfish (Clarias sp) is one of the important commodities in freshwater aquaculture in Indonesia. This fish has a large market potential because many are liked by consumers. 
The rate of growth of catfish and breeding is fast. Catfish is also one of the most popular fish consumption by the public. Catfish are relatively easy to maintain because they can live in oxygen-poor containers, fast growth, high production, faster harvesting, egg-laying ability and high egg hatchability, more resistant to disease, superior meat quality, and easy maintenance techniques as well as catfish traits which is greedy so it's easy to feed. The distinctive taste of catfish also makes this fish much in demand by people for consumption.

The disease caused by A. hydrophilla is called MAS (Motil Aeromonas Septicemia) or better known as red spot disease on the body of catfish. This disease can cause symptoms in catfish in the form of sudden death, lack of appetite, abnormally moving or swimming, pale gills, body dislection which eventually become ulcers. When a catfish is cultivated attacked by A. hydrophilla disease, it will be easy for the disease to infect the catfish that are cultivated in the same container. The emergence of the problem needs to be done the first few countermeasures are prevention, but if prevention fails then do treatment.

Turmeric contains medicinal compounds, called curcuminoids consisting of curcumin, desmetoxicumin as much as $10 \%$ and bisdesmetoxicurcumin as much as $1-5 \%$ and other beneficial substances such as essential oils consisting of sesquiterpenes ketones, turmerons, $60 \%$ tumeon, 25\% Zingiberen, felandren, sabinen, borneol and cineil. Turmeric also contains. Fat as much as $1-3 \%$, Carbohydrate as much as 3\%, Protein 30\%, Starch 8\%, Vitamin C $45-55 \%$, and mineral salts, namely iron, phosphorus, and calcium (Sastrahidayat, 2016).

Previous studies of turmeric include Simatupang (2013) turmeric containing curkominoids which play an active role as antimicrobials. Turmeric plants can overcome the attack of Aeromonas hydrophilla bacteria on sangkuriang catfish (Clarias sp). The hematocrit content in catfish infected with Aeromonas hydrophilla decreases from an average of 30\% to below $20 \%$. According to Saragih et al (2016) Immersion with curcumin extract infected with A. hydrophilla bacterial affects the blood picture of conjoined jambal fish (Pangasius hypophthalmus)

The results of previous studies conducted at the Bogor Institute of Agriculture showed that the bulbs of Dayak onion (Eleutherine palmifolia (L.) Merr) contained Nophtoquinonens compounds and their derivatives such as elecanacine, eleutherine, eleutherol, eleuthernon. Nophtoquinonens are known as antimicrobial, antifungal, antivirial and antiparasitic. In addition, Nophtoquinonens has bioactivity as an anticancer and antioxidant that is usually present in vacuole cells in the form of glycosides (Utami and Puspaningtyas, 2013). Ardiansyah (2016) in his research gave the result that in the rough extract of Dayak onions there were flavonoid compounds, tannins and saponins. A concentration of $70 \mathrm{ppm}$ Dayak onion gave the best results on the MIC Aeromonas hydrophilla test.

Overall turmeric and Dayak onions have different phytochemical contents so that they also have different ways to inhibit bacterial attack. So that between the two ingredients can be used to cure catfish from bacterial attack. However, the time to cure the two natural ingredients is not yet known which is faster.

\subsection{Formulation of the problem}


Catfish farming has been popular in every area, but the threat of good diseases caused by parasites, bacteria and viruses continues to threaten every year. One of the deadly and harmful diseases is Motile Aeromonas Septicimia (MAS) which is caused by Aeromonas hydrophilla bacterial infection. Treatment with antibiotics can cause residuals and bacterial resistance to increase, therefore it is necessary to use natural ingredients such as Dayak onion extract and turmeric extract have been effectively used. This study will examine variations in the use of dayak onion extract and turmeric extract used to treat catfish infections due to the attack of Aeromonas hydrophilla bacteria.

\subsection{Aim}

This study aims to examine the variation of natural ingredients turmeric extract and dayak onion extract on the treatment of sangkuriang catfish infected with Aeromonoas hydrophilla bacteria.

\subsection{The benefits}

The benefits of research variations of natural ingredients turmeric extract and dayak onion extract which are most effective in the treatment of sangkuriang catfish infected with Aeromonoas hydrophilla bacteria are as follows:

\section{a. For the World of Education:}

- As a treasure trove of the latest knowledge about the treatment of fish diseases using natural ingredients.

\section{b. For Cultivation Users}

- As a treatment for fish that uses herbal ingredients to overcome the bacterial infection of Aeromonas hydrophilla in sangkuriang catfish.

\section{LITERATURE REVIEW}

\subsection{Catfish (Clarias sp)}

According to Saanin (1984) and Gunawan (2009), based on the scientific classification of sangkuriang catfish is as follows:

Phylum: Chordata

Class: Pisces

Sub Class: Teleostei

Order: Ostariophysi

Family: Claridae

Genus: Clarias 
Species: Clarias gariepinus

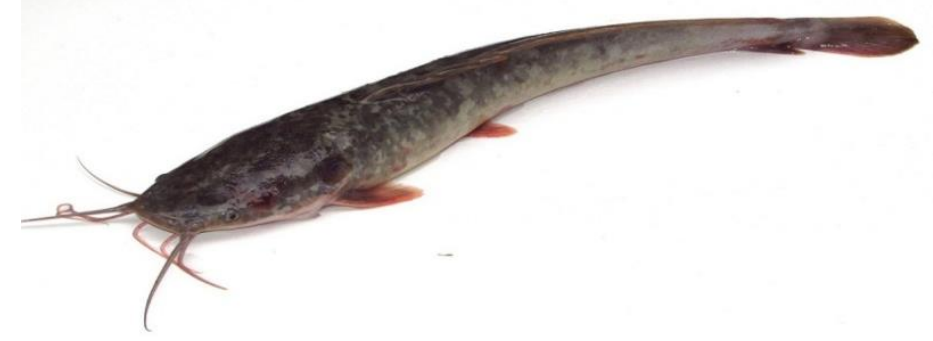

Figure 2.1. Catfish (Clarias gariepinus)

Source: special

Sangkuriang catfish is an improvement in the quality of African catfish that have decreased genetic quality by cross-linking. The back crossing is done by mating between the 6th generation male catfish broodstock (F6) with the 2nd generation female catfish broodstock (F2) (Syambas, 2011). Sangkuriang catfish has a slippery body, no scaly and slimy, has a wide mouth and is equipped with as many as four pairs of whiskers that function as a means of feeling when looking for food or moving. To facilitate swimming, sangkuriang catfish have single fins and paired fins. The sole fins are the dorsal, caudal and anal fins, while the paired fins are the pelvic and pectoral fins. The hard pectoral fins are called patiles, useful as weapons and moving aids. Sangkuriang catfish has a greenish black body color and a yellowish white belly (Rukmini, 2012). As according to Nasrudin (2010), sangkuriang catfish has a blackish green body color on the back and a yellowish white in the abdomen. The movement is less agile, the patile is poisonous, the biological properties of sangkuriang catfish can damage the embankment.

\subsection{Aeromonas hydrophilla bacteria}

Aeromonas hydrophila is a bacterium that causes pain in fish. Generally live in freshwater that contains high organic matter. The main characteristics of the Aeromonas hydrophila bacteria are rod-shaped, 0.3-1.0 $\mu \mathrm{m}$ in diameter and 1.0-3.5 $\mu \mathrm{m}$ long. A.hydrophila bacteria are gram negative, aerobic facultative (can live with or without oxygen), are not sporous and are motile (active) because they have a single flagellum (monotrichous flagella) that comes out of one of its poles (Cowan and Steel's, 1993)

The calcifications of Aeromonas hydrophila according to Percival et al (2014) are as follows:

Phylum: Protophyta

Class: Schizomycates

Order: Pseudomanadales

Family: Vibrionaceae 
Genus: Aeromonas

Species: Aeromonas hydrophila

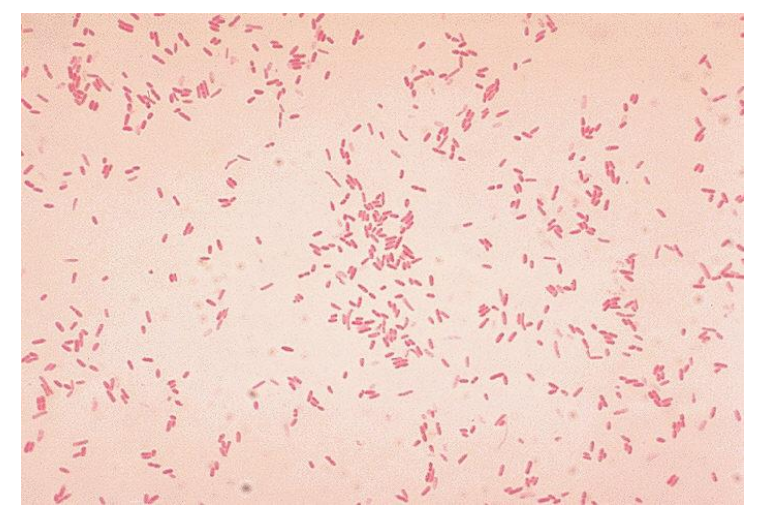

Figure 2.2 Aeromonas hydrophila bacteria

Aeromonas hydrophila is a Gram-negative, rod-shaped, motile bacterium. A. hydrophila is basically opportunistic because of diseases caused by outbreaks in stressed fish or in the maintenance of high stocking densities (Irianto, 2005).

Clinical signs of A. hydrophila infection vary, but are generally indicated by the presence of hemorrhagic on the skin, gills, oral cavity and ulcers on the skin that can extend to muscle tissue. Clinical signs are often also indicated by the occurrence of exoptalmia, ascites, spleen and kidney enlargement. Histopalogically there was a necrosis of the spleen, liver, kidneys and heart. Often bacteria are characterized by the appearance of bacterial cells in these tissues (Irianto, 2005).

\subsection{Turmeric (Curcuma domestica)}

Turmeric is a plant that is able to live in various regions in the world. Turmeric has various different regional names including kakunye (Sumatra), turmeric (Java), kunit (Kalimantan), turmeric (Nusa Tenggara), uinida (Sulawesi), kurlai (Maluku), rame (Irian), wat gam (Irian) (wat gam (Irian), China), ukon (Japan), arishina (Canada), haldi (India), kolkuma (Korea) and others. According to Syamsudin (1994) Turmeric classification is as follows:

Kingdom: Plantae

Subkingdom: Viridiplantae

Infrakingdom: Streptophyta

Superdivision: Embryophyta

Division: Tracheophyta 
Subdivision: Spermatophytina

Class: Magnoliopsida

Superorder: Lilianae

Order: Zingiberales

Family: Zingiberaceae

Genus: Curcuma V.

Species: Curcuma domestica

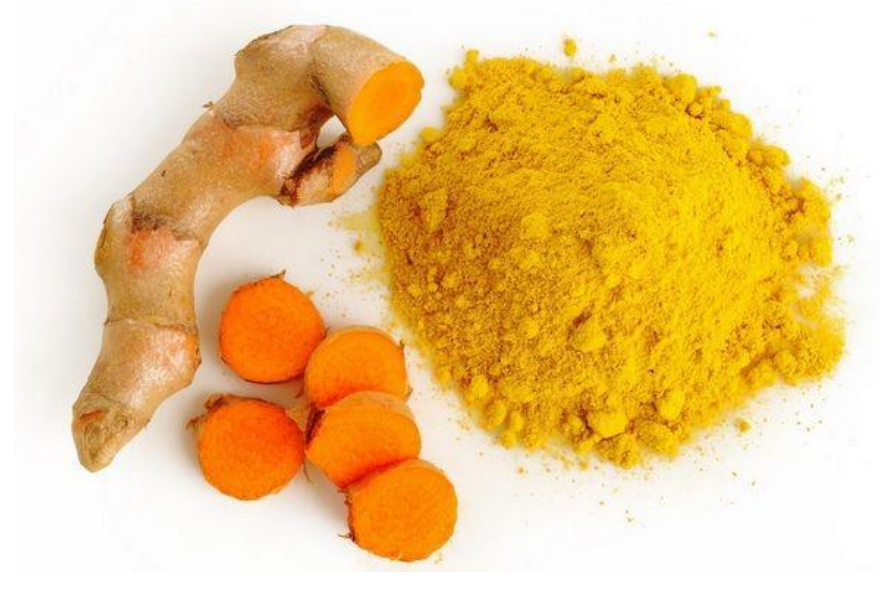

Figure 2.3. Turmeric (Curcuma domestica)

Turmeric plants are clumps with a height of 40-100 cm that have stems, leaves and flowers. Turmeric stems are pseudo stems, upright round in shape, composed of leaf midribs. Turmeric leaves are single, ovoid shape extends up to $10-40 \mathrm{~cm}$, width $8-12.5 \mathrm{~cm}$ and the bones of the leaves are pinned with pale green color. The tip and base of the leaves are pointy and the leaves are flat. Turmeric flower compound and hair scaly $10-15 \mathrm{~cm}$ long with a crown of about $3 \mathrm{~cm}$ long and $1.5 \mathrm{~cm}$ wide, white / yellowish. Turmeric rhizome measuring $2.5-7.0 \mathrm{~cm}$ (long), and 2.5 $\mathrm{cm}$ (diameter). The outer rind of the rhizome is brownish-orange with yellowish-red flesh of flesh (Karmila et al, 2017).

Turmeric is one of the plants of the Zingiberaceae family that is most frequently studied for its phytochemical content. At least there are phytochemical compounds that have been isolated from leaves, flowers and turmeric. These compounds include phenolic compounds, terpenes, sterols, alkaloids, and other compounds. Turmeric comes from the polyphenolic pigment commonly called curcuminoids. One of the main curcuminoids is curcumin (Samsundari, 2006).

\subsection{Dayak Onion (Eleutherine palmifolia (L.) Merr)}


One of the medicinal plants that has been developed especially in the Central Kalimantan region is the Dayak onion plant (Eleutherine palmifolia (L.) Merr). This plant has many types with various shapes and types such as onion, garlic and various other types of onions. The specific characteristics of this plant are

Taxonomically, Dayak onion plants have classification pathways, namely:

Kingdom: Plantae

Division: Spermatophyta

Subdivision: Angiosperms

Class: Monocotyledonae

Nation: Liliales

Tribe: Iridaceae

Surname: Eleutherine

Type: Eleutherine palmifolia (L) Merr (MOH, 2001).

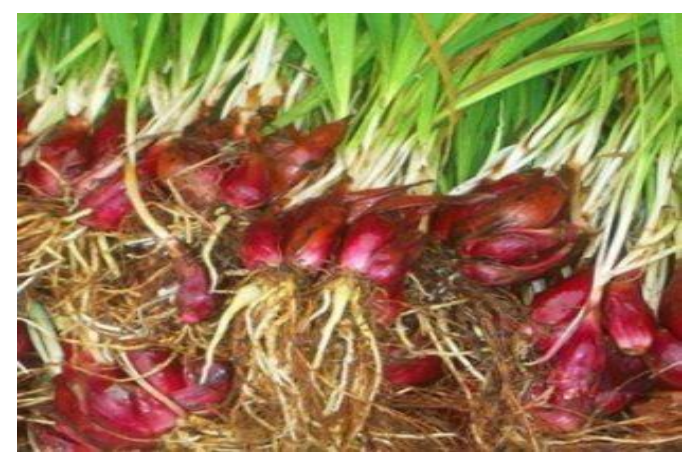

Figure 2.4. Dayak Onion (Eleutherine palmifolia (L) Merr)

Empirically, Dayak onion tubers are known to have properties to treat skin diseases. How to use it is by attaching grated Dayak onion tubers to the injured area. Empirically, the tubers are diuretic, astringent, laxative, analgesic, treat wounds, jaundice, coughing, bloody diarrhea, abdominal pain, dysentery, inflammation of the intestinal axis, colon cancer, breast cancer, breast cancer, vomiting, and boils. The leaves are efficacious as a medicine for postpartum women (Galingging, 2009). The special physiological properties of this plant are then carried out studies that are studies of the antimicrobial activity of Dayak bulbs on some skin microbes.

Satratilofa et al (2018) suggested that the method of extracting Dayak onions (Eleutherine palmifolia) with maceration both with $96 \%$ alcohol and $96 \%$ ethanol could inhibit the growth of Aeromonas hydrophilla bacteria on disc paper compared with the infusion and decoxy extraction 
methods. According to Akbar (2017) Dayak onions can also cure Saprolegnia sp. Between 104 to 263 hours.

\subsection{Haematological Fish}

According to Hastuti et al (2011) in conventional culture systems, catfish erythrocyte levels are $1.74 \times 10^{\wedge} 6$ cells / ul, $\mathrm{HB}$ is $7.8 \mathrm{~g} / \mathrm{dl}$ average hematocrit $23.33 \%$ and platelets average 42000 cells / ul, leukocytes averaged 107,570 cells / ul.

\subsubsection{Hematocrit}

Hematocrit is the percentage of erythrocyte volume in fish blood or a comparison between the volume of blood cells and blood plasma. Hematocrit can provide clues about fish health and help to determine the emergence of abnormalities due to the use of immunostimulants. Hematocrit values can be calculated through the number of red blood cells contained in fish blood (Januarty, 2012).

\subsubsection{Leukocrit}

Leukocytes in fish consists of seven forms, namely three types of eosinophils, granulocytes and each type of neutrophil granulocytes, lymphocytes, monocytes, and platelets. Eosinophils, neutrophils and monocytes are phagocytic leukocytes. Neutrophils and monocytes are strong phagocytes. One neutrophil can phagocyte 5-20 bacteria before the neutrophil becomes inactive and dies. Monocytes are stronger than neutrophils in phagositizing bacteria, they can even phagositize larger farticles. Therefore, mature monocytes are called macrophages and are able to phagocyte 100 bacteria. Limpocytes are not phagocytic but play an important role in the formation of antibodies. (Fujaya, 2004).

\subsubsection{Blood plasma}

Blood plasma consists of proteins that have variations in molecular weight and function. This difference depends on the individual and the environment, especially colloid osmotic pressure, temperature, and $\mathrm{pH}$. In addition, blood plasma is also an intermediary for transforming copper, iron, iodine, and lipids (Fujaya, 2004). Andesron siwicki (1994) in Januarty (2012), states that yellow blood plasma with slightly yellowish indicates normal fish, while reddish blood plasma shows abnormal fish due to erythrocytes lysis caused by cell fragility.

\subsubsection{Hemoglobin}

Hemoglobin is metalloporhyrin, a combination of haem / hem which is porphyrin iron and globin. Each hemoglobin elasmobransi and teleostei molecule contains four hem molecules, namely two $\alpha$ chains and two $\beta$ chains. Therefore, one hemoglobin molecule contains four iron atoms so that it can carry four oxygen molecules. There is a strong correlation between hematocrit and the amount of blood hemoglobin, the lower the red blood cells, the lower the amount of hemoglobin in the blood (Fujaya, 2004).

\section{RESEARCH METHOD}




\subsection{Time and place}

This Main Research was carried out in the Basic Laboratory of the Faculty of Fisheries, Lambung Mangkurat University for maintenance, the Basic Laboratory of the Faculty of Mathematics and Natural Sciences to extract Dayak onions and turmeric, Fish Quarantine Station, Quality Control and Safety of Fishery Products (SKIPM) Palangkaraya for bacterial testing .. Research This was carried out for 3 months from February to April 2019 covering the period of preparation, conducting research and making reports. The research can be seen in the following Table 3.1:

\subsection{Tools and materials}

\subsubsection{Tools used}

The tools used for extracting Dayak onions and turmeric extraction, isolation and bacterial culture are; blenders, rulers, scissors, erlenmeyer tubes, measuring cups, hot plates and stir plates, petri dishes, test tubes, beaker cups, bunsen lamps, curved loop, measuring pipettes, spatulas, glass mouthpieces, autoclaves, refrigerators, vortex (Fhir Whirlimixer), micropipette 10-100 $\mu \mathrm{l}$ and 100-1000 $\mu \mathrm{l}$, centrifuge, yellow tip, blue tip, gas stove, knife, shaker, cotton, plastic, rubber band, analytical balance, incubator, oven, rotary vacum evaporator. 12 pieces of basin with a volume of $20 \mathrm{~L}$, aquarium, $1 \mathrm{ml}$ disposable syiringe, scoop net, hose, hematocrit capillaries, and microsentrifuge tubes.

\subsubsection{Material used}

\section{a. Test Animals}

Test animals used were sangkuriang catfish size 7-13 cm with a weight of 18-25 grams, taken from BBI Bincau. The fish were acclimatized for 5 days, after which the fish were taken blood for preliminary data.

\section{b. Dayak Onions}

Dayak onions used in this study were obtained from the District of Landasan Ulin, Banjarbaru City, South Kalimantan Province.

\section{c. Turmeric}

Turmeric used in this study was obtained from Bauntung Market, Banjarbaru City, South Kalimantan Province.

\section{c. Material for extraction of Dayak Onions and Turmeric}

The material used is $96 \%$ ethanol to soak (maceration) Dayak onion powder and turmeric powder.

\section{d. Aeromonas hydrophila isolates and culture media}


The bacterial isolate of A. hydrophila was obtained from the collection of the Laboratory of Environmental Health and Fish Disease BPBAT Mandi Breeze South Kalimantan. The culture media used were Aeromonas-Pseudomonas (GSP Agar) selective media, culture stock medium and sensitivity test for A. hydrophila namely TSA (Tryptone soya Agar), medium for liquid stock of A. hydrophila bacteria namely TSB (Tryptone soya Broth), solid medium bacto agar, methanol $(\mathrm{MeOH})$ and aquades.

\section{e. Material for Leukocrit and Hematocrit Measurement}

Materials used include; fish blood samples, anti-coagulant (EDTA), $0.1 \mathrm{~N} \mathrm{HCl}$ solution, distilled water, methanol, alcohol.

\section{f. Fish feed}

The feed used in the maintenance period is HI-PRO-Vite 781. Commercial feed. This fish feed is a type of floating fish feed specially formulated for catfish culture with 31-33\% Protein content, 4-6\% Fat, 4-6\% Water Content 10\% Feeding is done 2 times a day in the morning and evening.

\subsection{Research procedure}

\subsubsection{Preparation}

\section{a. Preparation of Equipment and Materials}

The basin that will be used for raising catfish is soaked in clean water for one night to remove the plastic odor. The basin is soaked with chlorine to wash the plastic basin for 1 night, then air dried.

\section{b. Dayak Onion Extract}

Dayak Onions used are fresh dayak onions with a total wet weight of around $2 \mathrm{~kg}$. first the fresh Dayak onions are washed clean then allowed to air dry until the remaining water is gone. Fresh onions are cut into small pieces using a knife and then weighed as a coarse weight. Then do the oven at $50 \mathrm{oC}$ until dry onions are obtained, then mashed using a blender to get dayak onions in powder form.

Dayak finely soaked (maceration) with ethanol $96 \%$ for 24 hours at room temperature with a ratio of 1: 4 ie $1 \mathrm{~g}$ of dayak onion powder, soaked in $4 \mathrm{~mL}$ ethanol. The obtained solution is then filtered with filter paper and then evaporated with a rotary vacum evaporator so that a coarse extract of Dayak onions is produced in the form of a paste.

\section{c. Turmeric Extract}

Turmeric used is fresh turmeric with a total wet weight of around $2 \mathrm{~kg}$. first the fresh turmeric is washed clean then allowed to air dry until the water is still attached to disappear until the air dries. Fresh onions are cut into small pieces using a knife and weighed as a coarse weight, carried out at a temperature of $50 \mathrm{oC}$ until dried turmeric is obtained, then mashed using a blender to get turmeric in powder form. 
Turmeric that has been finely soaked (maceration) in ethanol $96 \%$ for 24 hours at room temperature with a ratio of $1: 4$ ie $1 \mathrm{~g}$ turmeric soaked in $4 \mathrm{~mL}$ ethanol. The obtained solution is then filtered with filter paper and then evaporated with a rotary vacuum evaporator so that the turmeric crude extract is produced in the form of a paste.

\section{c. Bacterial Rejuvenation}

The bacteria A. hydrophila in sloping agar (stock culture) is rejuvenated by culture on a selective GSP agar medium and incubated at room temperature for 18-24 hours. The yellow colonies were moved partly to the TSA (Tryptone soya Agar) sloping medium which was then given liquid paraffin as a stock culture and partly moved into the $\mathrm{NaCl}$ liquid medium as the initial bacterial culture medium. Increased virulence of bacterial isolates Bacteria that will be used in antibacterial activity tests will first be reinfected and re-isolated to increase virulence. Reinfection is carried out by intramuscular injection at a dose of $0.1 \mathrm{ml}(109 \mathrm{cfu} / \mathrm{ml})$ in catfish. Catfish that have been infected are kept in a $20 \mathrm{~L}$ volume basin, after which the fish are observed and treated with the same dosage. If a catfish is found dead or has symptoms of a severe disease, then it is carried out re-isolation (surgery to take the active bacteria). The bacterial isolation of A. hydrophila from catfish samples was aseptically taken from the kidney organ using sterile ose in a selective GSP agar medium and incubated at room temperature for 18-24 hours. The 2nd and 3rd reinfection and isolation to increase the virulence of A. hydrophila bacteria. The method used is the same as reinfection and first reolation.

\section{g. Sampling}

Blood samples were taken 3 times namely after immersion, one week maintenance after immersion and two weeks after immersion. Growth measurements carried out 2 times, namely the beginning and end. Likewise with water sampling for water quality testing carried out as 2 times at the beginning and end of the study.

\subsubsection{Main Research}

\section{a. Catfish Preparation}

Sangkuriang catfish are placed in each treatment unit as much as 10 individuals per container with a size between 10-20 cm and a weight of 25-50 grams after minimizing for a minimum of 14 days.

\section{b. Aeromonas hydrophilla bacterial infection}

Bacterial infection is carried out after 1 day of catfish put into the treatment container by means of intraperitonial at a dose of $10-8 \mathrm{CFU}$.

\section{c. Soaking with Dayak onion extract and turmeric extract}

Fish were infected for 6 hours, so the treatment unit was immersed in each extract in accordance with the treatment for 36 hours.

\section{b. Measurement of Hematocrit, Leukocrit and Blood Plasma.}


Hematocrit and leukocrit measurements were made after the completion of treatment at the beginning of water replacement, 10 days after treatment and 17 days after treatment. Measurements were made by taking a blood sample using a $1 \mathrm{~mL}$ disposable syring that was moistened with anti-coogulant (EDTA) in fish. The blood is collected in microscentrifuge tubes. Blood is inserted into the hematocrit capillaries to the volume limit and covered with wax. After that, the hematocrit capillaries are centrifuged at $1000 \mathrm{rpm}$ for 5 minutes. The length of the volume of erythrocytes, leukocytes and blood plasma is measured in length using a ruler after measuring the volume presentation.

\section{d. Measurement of Hemoglobin Concentration}

Measurement of blood hemoglobin concentration was carried out using the sahli method. The diluent tube is filled with $0.1 \mathrm{~N} \mathrm{HCl}$ solution up to number 2. Enter $20 \mu \mathrm{l}$ of catfish blood into the diluent tube and mixed with pipetting, after that add sterile distilled water little by little until the color of the solution is the same as the standard color. The height of the solution according to the scale shows the level ( $\mathrm{hb}$ ) in fish blood ( $\mathrm{gr} / \mathrm{dl}$ ).

\section{e. Observation of Mortality}

Observation of mortality in catfish is done every day starting when catfish are put into a research container for acclimatization.

\section{f. Water quality}

Observation of water quality is carried out at the beginning and end of the treatment. Some parameters of water quality observed were temperature, degree of pressure $(\mathrm{pH})$, dissolved oxygen (DO) and ammonia.

\subsection{Experiment Design}

The experimental design used in this study was a Completely Randomized Design (CRD) of 5 (five) treatments with 3 replications plus positive and negative controls, as for the following treatments:

$\mathrm{A}=$ concentration of dayak extract (EBD) $100 \mathrm{ppm}$ and turmeric extract (EK) $0 \mathrm{ppm}$

$\mathrm{B}=$ concentration of dayak onion extract (EBD) $75 \mathrm{ppm}$ and turmeric extract (EK) $25 \mathrm{ppm}$

$\mathrm{C}=$ concentration of dayak onion extract (EBD) $50 \mathrm{ppm}$ and turmeric extract (EK) $50 \mathrm{ppm}$

$\mathrm{D}=$ concentration of dayak extract (EBD) $25 \mathrm{ppm}$ and turmeric extract (EK) $75 \mathrm{ppm}$

$\mathrm{E}=$ concentration of dayak onion extract (EBD) $0 \mathrm{ppm}$ and turmeric extract (EK) $100 \mathrm{ppm}$

$\mathrm{K} 1=$ Positive Control ie fish infected with Aeromonas hydrophilla

K2 = Negative Control, ie healthy fish (not infected). 
There are 5 combinations in this experimental design with 3 replications to produce 15 experimental units. Placement of the test unit can be seen in the image below

\begin{tabular}{|c|c|c|c|c|c|}
\hline E3 & A3 & B1 & A2 & C3 & E1 \\
\hline C2 & D1 & E2 & D3 & K2 & B2 \\
\hline-- & K1 & A1 & D2 & B3 & C1 \\
\hline
\end{tabular}

Figure 4. Placement of Experiment Units

\title{
3.5 Observation
}

\subsubsection{Survival}

Fish survival is observed every day until the end of the treatment, survival calculation is done at the end of the treatment with a formula like the following (Effendi, 2004) in (Sartika, 2011).

\author{
Number of live fish at \\ Kelangsungan Hidup $=\frac{\text { the end of the study }}{\text { The number of fish at }} \times 100 \%$ \\ the beginning of the
}

\subsubsection{Measurement of Hematocrit, Leukocrit and Blood Plasma}

The measurement is done by taking a blood sample using a $1 \mathrm{ml}$ disposable syring that has been moistened with anti-coagulant (EDTA) in fish. The blood is collected in micros centrifuge tubes. Blood is inserted into the hematocrit capillaries to the volume limit and covered with wax. Hematocrit capillaries in centrifuges with a speed of $1000 \mathrm{rpm}$ for 5 minutes. The length of the volume of erythrocytes, leukocytes and blood plasma is measured in length using a ruler. Calculated in volume presentation, the calculation formula for hematocrit, leukocrit and blood plasma according to (Anderson and Siwicki, 1994) is as follows.

$$
\begin{aligned}
& \text { Hematokrit }=\quad \frac{\text { Erythrocytes }}{\text { Total blood }} \times 100 \% \\
& \text { Leukokrit }=\quad \frac{\text { Leukocytes }}{\text { Total blood }} \times 100 \%
\end{aligned}
$$

Blood Plasma $=$ Total Blood Amount - Leukocytes - Erythrocytes

\subsubsection{Measurement of Hemoglobin Concentration}


Measurement of blood hemoglobin concentration was carried out using the sahli method. The diluent tube is filled with $0.1 \mathrm{~N} \mathrm{HCl}$ solution up to number 2. Enter $20 \mu \mathrm{l}$ of catfish blood into the diluent tube and mixed with pipetting. Add sterile distilled water little by little until the color of the solution is the same as the standard color. The height of the solution according to the scale indicates the level ( $\mathrm{hb})$ in fish blood $(\mathrm{gr} / \mathrm{dl})$.

\subsubsection{Water Quality}

Observation of water quality is carried out at the beginning and end of the treatment. Some parameters of water quality observed were temperature, degree of pressure $(\mathrm{pH})$, dissolved oxygen (DO) and ammonia.

\subsection{Hypothesis}

\section{The hypothesis used is:}

$\mathrm{H} 0=$ Treatment with a variety of natural ingredients turmeric extract and dayak onion extract did not significantly affect the sangkuriang catfish infected with Aeromonoas hydrophilla bacteria.

$\mathrm{H} 1$ = Treatment with a variety of natural ingredients turmeric extract and dayak onion extract significantly affect sangkuriang catfish infected with Aeromonoas hydrophilla bacteria.

\subsection{Data analysis}

The research data obtained has the possibility to be abnormal due to variations in the field or mistakes made, then the data needs to be tested for normality with the Lilliefors test (Nasoetion and Barizi, 1985), tested for homogeneity using the Bartlett homogeneity test (Sudjana, 1992). If the data is not normal or not homogeneous, then before the diversity is analyzed the data is transformed first. The data is normal and homogeneous, so the diversity can be analyzed by analysis of variance to determine whether or not there is an influence of each treatment. If there is a real or very real difference then proceed with further tests, as according to Hanafiah (2005) and calculated using the SPSS application.

\section{RESULTS AND DISCUSSION}

\subsection{Life sustainability}

Survival rate (SR) is a percentage of the number of fish that live during the study period. Data on the number of fish from the treatment and the calculation of life class (\%) at the end of the study of catfish during the treatment period can be seen in the following Table 4.1. 
Table 4.1 Percentage of Survival of Catfish During the Study

\begin{tabular}{|c|c|c|c|c|c|c|c|}
\hline \multirow{2}{*}{$\begin{array}{c}\text { Life } \\
\text { sustainability }\end{array}$} & \multicolumn{7}{|c|}{ Perlakuan } \\
\cline { 2 - 9 } & $\mathbf{A}$ & $\mathbf{B}$ & $\mathbf{C}$ & $\mathbf{D}$ & $\mathbf{E}$ & $\mathbf{K 1}$ & $\mathbf{K 2}$ \\
\hline $\begin{array}{c}\text { Preliminary } \\
\text { Average }\end{array}$ & 10 & 10 & 10 & 10 & 10 & 10 & 10 \\
\hline Final Mean & 8,33 & 7,67 & 8,67 & 8,33 & 8,33 & 5 & 10 \\
\hline Percentage & 83,33 & 76,67 & 86,67 & 83,33 & 83,33 & 50 & 100 \\
\hline
\end{tabular}

Information :

A = ILS infected by A.hydrophilla and treated with EBD 100 ppm and EK 0 ppm

$\mathrm{B}=$ ILS infected with A.hydrophilla and treated with EBD 75 ppm and EK 25 ppm

$\mathrm{C}=$ ILS was infected with A.hydrophilla and treated with EBD 50 ppm and EK 50 ppm

$\mathrm{D}=$ ILS was infected with A.hydrophilla and treated with EBD 25 ppm and EK 75 ppm

$\mathrm{E}=\mathrm{ILS}$ was infected with A.hydrophilla and treated with EBD 0 ppm and EK $100 \mathrm{ppm}$

K1 = ILS infected by A.hydrophilla bacteria (Positive Control)

$\mathrm{K} 2$ = ILS injected with $\mathrm{NaCl}$ (Negative Control)

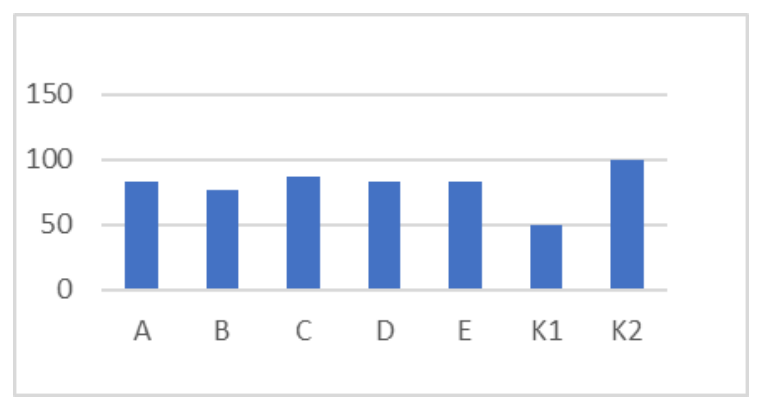

Figure 4.1 Graph Average Percentage of Survival of Sangkurtiang Catfish During Research

Table 4.1 shows that the survival of catfish was lowest in treatment B with a value of $76.66 \%$ with a variation of $75 \mathrm{ppm}$ onion extract and turmeric extract $25 \mathrm{ppm}$, the highest in $\mathrm{C}$ treatment was $86.66 \%$ with a variation of $75 \mathrm{ppm}$ onion extract, whereas in treatments $\mathrm{A}, \mathrm{D}$ and $\mathrm{E}$ are both $83 \%$. Previous research by Karmila et al (2017) average survival of catfish infected with Aeromonas hydrophilla bacteria and treated using turmeric extract with high concentration levels above $200 \mathrm{ppm}$ average survival rate of 50.62\%, when compared with studies this results in a higher level of survival. The use of variations of turmeric and dayak onions can make survival higher than previous studies. 
Table 4.2 can be seen ANOVA test results of survival rates of catfish during maintenance showed very significant different results, where $\mathrm{F}$ count $>\mathrm{F}$ table $5 \%$ and $1 \%$ which means there is a real influence between treatments statistically. Normality test before ANOVA jewelry on the survival of catfish during the maintenance period showed that the data was spread normally. Homogeneity test shows that homogeneous survival rate data is significant at 0.002 . After further testing both Duncan and Tukey the difference between treatments A, B, C, D and E was only significantly different from $\mathrm{K} 2$, this states that the treatment of both $\mathrm{A}, \mathrm{B}, \mathrm{C}, \mathrm{D}$ and $\mathrm{E}$ could significantly influence if compared with positive controls. Between treatments A, B, C, D and E there were no significant differences and were still in 1 group with $\mathrm{K} 2$ (negative control). There was no significant difference between treatments A, B, C, D and E, also marked by level.

\subsection{Value of Hematocrit, Leukocrit and Blood Plasma of Catfish}

\subsubsection{Value of Hematocrit Catfish}

Hematocrit is the percentage of erythrocyte volume in fish blood or a comparison between the volume of blood cells and blood plasma. Hematocrit values can be calculated through the number of red blood cells contained in fish blood. The hematocrit content also depends on factors of nutrition, age, sex, body size. The results of hematocrit calculations during the study can be seen in Table 4.2 and Figure 4.3 below.

Table 4.3 Catfish Hematocrit Value (\%)

\begin{tabular}{|c|c|c|c|c|c|c|c|}
\hline \multirow{2}{*}{$\begin{array}{c}\text { Hematocrit } \\
\text { Value }\end{array}$} & \multicolumn{7}{|l|}{ Treatment } \\
\hline & A & B & $\mathrm{C}$ & $\mathrm{D}$ & E & $\mathrm{K} 1$ & $\mathrm{~K} 2$ \\
\hline $\begin{array}{l}\text { Post } \\
\text { Treatment }\end{array}$ & 9,00 & 4,67 & 4,67 & 3,00 & 2,33 & 1,00 & 31,00 \\
\hline $\mathrm{H}+10 \mathrm{PP}$ & 10,33 & 9,00 & 11,33 & 9,67 & 10,67 & 6,00 & 28,00 \\
\hline $\mathrm{H}+17 \mathrm{PP}$ & 17,67 & 19,33 & 17,33 & 20,67 & 17,00 & 5,00 & 30,00 \\
\hline amount & 37,00 & 33,00 & 33,33 & 33,33 & 30,00 & 12,00 & 89,00 \\
\hline Average & 12,33 & 11,00 & 11,11 & 11,11 & 10,00 & 4,00 & 29,67 \\
\hline
\end{tabular}

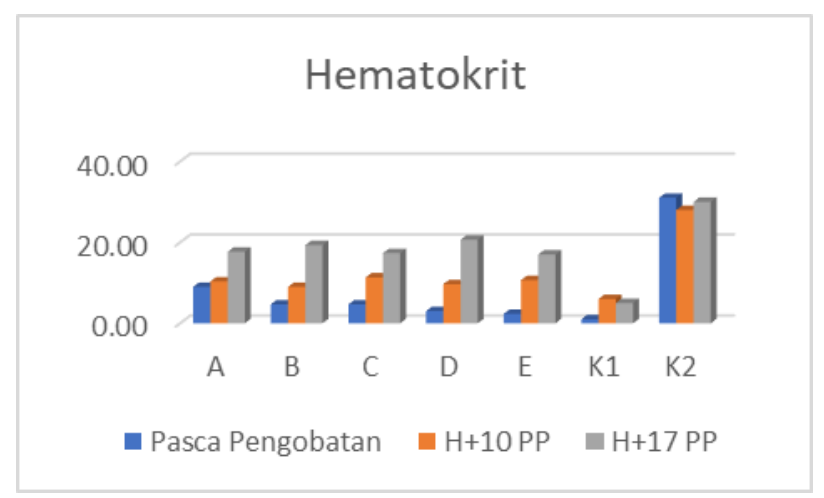


Figure 4.2 Hematocrit Value

Information :

A = ILS infected by A.hydrophilla and treated with EBD 100 ppm and EK 0 ppm

B = ILS infected with A.hydrophilla and treated with EBD 75 ppm and EK 25 ppm

$\mathrm{C}=$ ILS was infected with A.hydrophilla and treated with EBD 50 ppm and EK 50 ppm

$\mathrm{D}=$ ILS was infected with A.hydrophilla and treated with EBD 25 ppm and EK 75 ppm

$\mathrm{E}=\mathrm{ILS}$ was infected with A.hydrophilla and treated with EBD 0 ppm and EK 100 ppm

K1 = ILS infected by A.hydrophilla bacteria (Positive Control)

$\mathrm{K} 2=$ ILS injected with $\mathrm{NaCl}$ (Negative Control)

Based on table 4.3 and graph 4.3, after treatment the hematocrit value in the treatment ranges from 2.33 to 9.00 approaching the positive control hematocrit value (K1) and far when compared to the negative control hematocrit value (K2) this indicates the influence of the disease is still there and fish are still adjusting to the disease. Day 10 after treatment the hematocrit value has started to rise in the range of 9.00 to 11.33 has left the value of a positive control of 6.00 . At the end of the study the hematocrit value had increased between 17.00 to 20.00. Dopongtonung (2008) The range of hematocrit that catfish profiles in the Laladon area - Bogor ranges from 16.00 to 24.00, although according to Bondall (1979) in Dopongtonng (2008) the normal range of freshwater hematocrit fish is between $20 \mathrm{~s} / \mathrm{d} 30$. From these results that the range of final research is the same as the average catfish found on the market.

Another opinion, according to Maryani (2003), a hematocrit value smaller than $22 \%$, indicates that fish have anemia and are likely to be infected with the disease when compared to observations on the 17th day of the study, it has shown signs of healing. The addition of other supplements in the diet to increase hematocrit levels may be continued in other studies.

\subsubsection{Value of Leukocrit Catfish}

Fish leukocytes are part of the body's defense system that is non specific. Leukocytes circulate in various types in the blood vessels. Leukocytes circulate less in number than red blood cells. Leukocrit is a percentage of leukocyte volume in blood volume (Morgan and Iwama, 1997). The results of leukocrit analysis during the study period can be seen in Table 4.11 and Figure 4.8 below:

Table 4.7 Catfish Leukocyte Value (\%) 


\begin{tabular}{|l|c|c|c|c|c|c|c|}
\hline Treatment & A & B & C & D & E & K1 & K2 \\
\hline $\begin{array}{l}\text { Post } \\
\text { Treatment }\end{array}$ & 5,00 & 7,00 & 9,33 & 6,67 & 13,33 & 24,00 & 9,00 \\
\hline H+10 PP & 12,67 & 14,00 & 12,67 & 11,67 & 14,00 & 18,00 & 10,00 \\
\hline H+17 PP & 4,00 & 8,33 & 8,67 & 2,67 & 7,00 & 17,00 & 12,00 \\
\hline amount & 21,67 & 29,33 & 30,67 & 21,00 & 34,33 & 59,00 & 31,00 \\
\hline Average & 7,22 & 9,78 & 10,22 & 7,00 & 11,44 & 19,67 & 10,33 \\
\hline
\end{tabular}

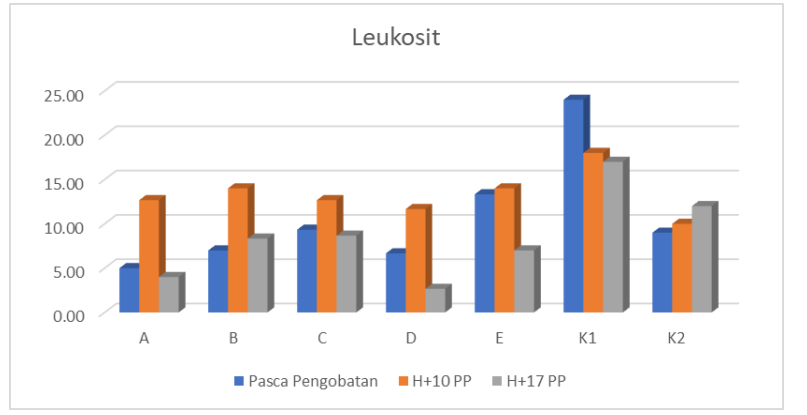

Figure 4.3 Leukocyte Value of Catfish

$\mathrm{A}=\mathrm{ILS}$ infected by A.hydrophilla and treated with EBD $100 \mathrm{ppm}$ and EK 0 ppm

$\mathrm{B}=$ ILS infected with A.hydrophilla and treated with EBD 75 ppm and EK 25 ppm

$\mathrm{C}=$ ILS was infected with A.hydrophilla and treated with EBD $50 \mathrm{ppm}$ and EK $50 \mathrm{ppm}$

$\mathrm{D}=$ ILS was infected with A.hydrophilla and treated with EBD $25 \mathrm{ppm}$ and EK $75 \mathrm{ppm}$

$\mathrm{E}=$ ILS was infected with A.hydrophilla and treated with EBD 0 ppm and EK 100 ppm

K1 = ILS infected by A.hydrophilla bacteria (Positive Control)

$\mathrm{K} 2$ = ILS injected with $\mathrm{NaCl}$ (Negative Control)

Table 4.7 and Figure 4.3 show leukocyte values in percent, where post-treatment shows various values with a range of 2.67 on the 17th day of PP in treatment D and the highest value is 14 on the 10th day of PP on treatment B. Control

\subsubsection{Catfish Blood Plasma Values}

Data for blood plasma analysis can be seen in Table 4.15 and Figure 4.5 below: 
Table 4.11 Catfish Blood Plasma Values

\begin{tabular}{|l|c|c|c|c|c|c|c|}
\hline Treatment & A & B & C & D & E & K1 & K2 \\
\hline $\begin{array}{l}\text { Post } \\
\text { Treatment }\end{array}$ & 86,00 & 88,33 & 86,00 & 90,33 & 84,33 & 75,00 & 60,00 \\
\hline H+10 PP & 77,00 & 77,00 & 76,00 & 78,67 & 75,33 & 76,00 & 62,00 \\
\hline H+17 PP & 78,33 & 72,33 & 74,00 & 76,67 & 76,00 & 78,00 & 58,00 \\
\hline amount & 241,33 & 237,67 & 236,00 & 245,67 & 235,67 & 229,00 & 180,00 \\
\hline & 80,44 & 79,22 & 78,67 & 81,89 & 78,56 & 76,33 & 60,00 \\
\hline
\end{tabular}

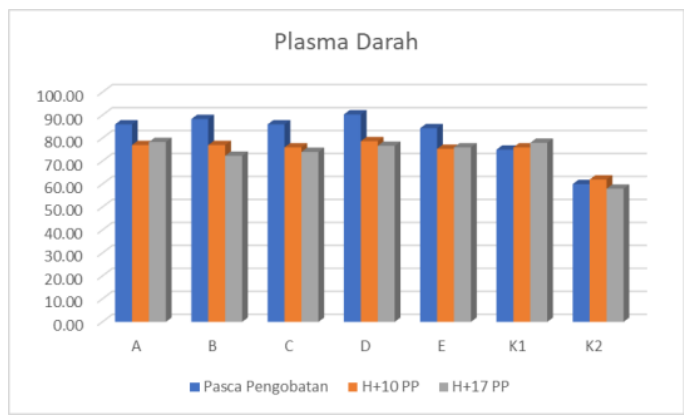

Figure 4.4 Catfish Blood Plasma Values

$\mathrm{A}=\mathrm{ILS}$ infected by A.hydrophilla and treated with EBD $100 \mathrm{ppm}$ and EK 0 ppm

$\mathrm{B}=$ ILS infected with A.hydrophilla and treated with EBD 75 ppm and EK 25 ppm

$\mathrm{C}=$ ILS was infected with A.hydrophilla and treated with EBD $50 \mathrm{ppm}$ and EK $50 \mathrm{ppm}$

D = ILS was infected with A.hydrophilla and treated with EBD 25 ppm and EK 75 ppm

$\mathrm{E}=$ ILS was infected with A.hydrophilla and treated with EBD 0 ppm and EK 100 ppm

K1 = ILS infected by A.hydrophilla bacteria (Positive Control)

$\mathrm{K} 2$ = ILS injected with $\mathrm{NaCl}$ (Negative Control)

Blood plasma is a component of blood in the form of yellow liquid which becomes a medium for blood cells, where blood cells are closed. 55\% of the amount / volume of blood is blood plasma. Blood plasma which has an important function is serum, this serum is blended separated by its fribrinogen. Bright and clear and contains antibodies to destroy foreign proteins that enter the body.

Blood plasma contains $90 \%$ water and a variety of aqueous solutions of $7 \%-10 \%$, proteins $7 \%$, Salts $1 \%$, Pleated $0.6 \%$, Glucose $0.1 \%$ Substances contained in blood plasma, namely food 
juices, hormone enzymes, minerals, antibodies and waste materials such as $\mathrm{CO} 2$ and protein disassembly. The food juices are absorbed by the small intestine.

Hematocrit is the percentage of red blood cells in the blood, if the hematocrit level is $40 \%$, it means that the blood consists of $40 \%$ red blood cells and $60 \%$ plasma and white blood cells. The results of an examination of hematocrit can be used as an indicator to determine the state of health of fish. Freshwater fish are said to be healthy if the hematocrit levels range between 22$60 \%$. If the hematocrit of fish is less than $22 \%$, it is stated that anemia is occurring, similarly if the hematocrit value is greater than 60\%, it indicates that the fish is under stress (Tsuzuki et al in Winarni 1997). Hematocrit levels vary depending on nutritional factors, fish age, sex, body size and spawning period (Kuswardani, 2006).

\subsection{Hemoglobin Value}

Hemoglobin $(\mathrm{Hb})$ is an erythrocyte pigment consisting of iron-containing complex conjugated proteins. Hb protein is globin, while the red color of hemoglobin is caused by the presence of heme. Heme is a metallic compound containing one iron atom (Guyton 1997). Hemoglobin physically has an important relationship with oxygen. When erythrocytes pass through the capillaries of the lungs, hemoglobin binds to oxygen to form oxyhemoglobin. Conversely, when passing through systemic capillaries, hemoglobin will release oxygen to the tissue and become hemoglobin again (Swenson, 1977 in Dopongtonung, 2008). Hemoglobin levels are consistent with the amount of erythrocytes, the higher the hemoglobin level the higher the number of erythrocytes. Hemoglobin levels are related to the number of erythrocytes, but not necessarily correlate with the number of erythrocytes because hemoglobin is a content of red blood cell pigment. Hemoglobin levels did not change significantly, even though the number of erythrocytes rose (Lagler et. Al, 1977). Hemoglobin analysis during maintenance was carried out 3 times ie before post-treatment, 10th day after treatment and 17th day post-treatment. The results of the analysis of hemoglobin values can be seen in Table 4.2 and Figure 4.2 below.

\section{Table 4.14 Catfish Hemoglobin Values}

\begin{tabular}{|c|c|c|c|c|c|c|c|}
\hline Treatment & A & B & C & D & E & K1 & K2 \\
\hline $\begin{array}{c}\text { Post } \\
\text { Treatment }\end{array}$ & 4,13 & 2,73 & 3,67 & 2,93 & 4,20 & 2,17 & 7,27 \\
\hline H+10 PP & 5,20 & 6,67 & 5,37 & 7,07 & 5,67 & 3,33 & 9,00 \\
\hline $\mathrm{H}+17$ PP & 5,67 & 6,27 & 5,53 & 5,33 & 5,53 & 3,70 & 7,73 \\
\hline amount & 15,00 & 15,67 & 14,57 & 15,33 & 15,40 & 9,20 & 24,00 \\
\hline Average & 5,00 & 5,22 & 4,86 & 5,11 & 5,13 & 3,07 & 8,00 \\
\hline
\end{tabular}




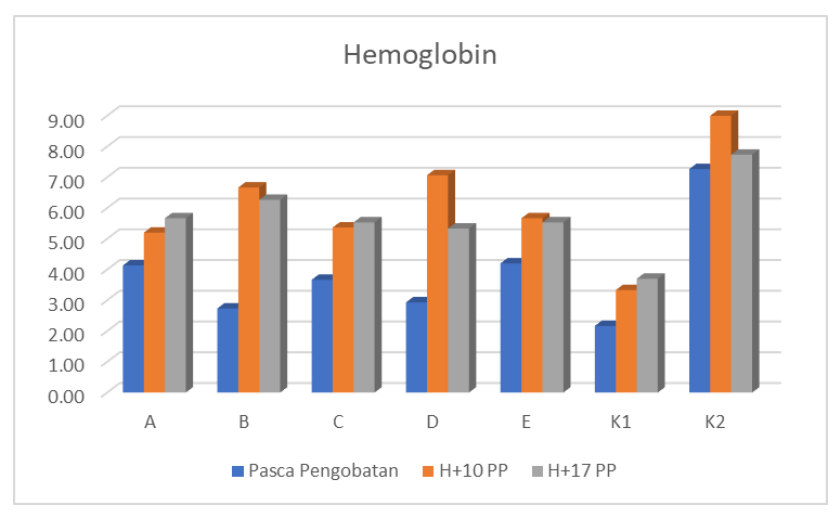

Figure 4.5 Catfish Hemoglobin Value

Information :

$\mathrm{A}=$ ILS infected by A.hydrophilla and treated with EBD 100 ppm and EK 0 ppm

$\mathrm{B}=$ ILS infected with A.hydrophilla and treated with EBD 75 ppm and EK 25 ppm

$\mathrm{C}=$ ILS was infected with A.hydrophilla and treated with EBD 50 ppm and EK 50 ppm

$\mathrm{D}=\mathrm{ILS}$ was infected with A.hydrophilla and treated with EBD $25 \mathrm{ppm}$ and EK $75 \mathrm{ppm}$

$\mathrm{E}=\mathrm{ILS}$ was infected with A.hydrophilla and treated with EBD 0 ppm and EK 100 ppm

K1 = ILS infected by A.hydrophilla bacteria (Positive Control)

$\mathrm{K} 2$ = ILS injected with $\mathrm{NaCl}$ (Negative Control)

Table 4.14 and Figure 4.5 about the value of Hemoglobin in catfish that were observed showed different results in each treatment and each time analysis. On the post-treatment day the $\mathrm{Hb}$ value was still low in the range of 2.73 to 4.20 close to the positive control value of 2.17 while the negative control was still 7.27. On the 10th day after treatment, the $\mathrm{Hb}$ value was in the range of 5.2 in treatment $\mathrm{A}$ and the highest at $7.07 \mathrm{D}$ which was approaching negative control at 9.0. The value of hemoglobin on the 17th day post-treatment is in the range of 5.53 to 6.27 . The highest hemoglobin value at the end of the study was in treatment $\mathrm{B}, 6.27$, which is already close to the normal value at 7.73. Nafiqoh (2018) catfish which were fed using a combination of betel leaf, guava and kipahit showed a hemoglobin value between 2.8 to 4.1 , whereas in this study it had shown a value of 6.27 to 7.73 at the end research. This indicates that treatment by soaking with turmeric extract and Dayak onion extract can be better.

Homogeneity test was obtained at 0.03 so that it was still significant (below 0.05) of the homoglobin value in catfish. Table 4.15 in the ANOVA test obtained F 8.964 and a significant 
value of 0.000 . In the follow-up test the significance value was divided into two groups, namely $\mathrm{K} 1$ (positive control), treatments $\mathrm{A}, \mathrm{B}, \mathrm{C}, \mathrm{D}, \mathrm{E}$ and in the second group namely $\mathrm{K} 2$ (negative control). This indicates the HB value both in the treatment and positive control conditions are equally in one group or the effect of the treatment still does not increase the fish HB value because catfish are still struggling to fight bacterial attack infections.

Tables 4.16 and 4.17 can be seen post-treatment $\mathrm{H}+10$ or $\mathrm{H}+17$, the results of ANOVA testing showed insignificant results $(0.279$ and 0.157$)$. This insignificant value is assumed because of the large error or data variance, causing homogeneity to be insignificant. In the post-treatment position on the 10th day, the $\mathrm{HB}$ value in treatment $\mathrm{D}$ was the highest value, almost approaching negative control, while at the end of the study, treatment $\mathrm{B}$, which had the highest $\mathrm{HB}$ value, approached negative control, while treatment $\mathrm{D}$ fell from the $\mathrm{H}+10$ position. The decrease in $\mathrm{HB}$ at the end of the study compared to the previous time did not have a significant value.

From the data above it can be seen that the effect of treatment with a variety of natural extracts has a positive effect on up to the tenth day after treatment, while the following week has had no effect anymore. The value of catfish hemoglobin concentration in this study seen in Figure 4.5 is still in the normal range of $6.50-11.47 \mathrm{~g} / \mathrm{dl}$. According to Salasia, et al (2001) Freshwater fish hemoglobin concentrations ranged from $5.05-8.33 \mathrm{gr} / \mathrm{dl}$.

The concentration of catfish hemoglobin values in this study were higher compared to normal carp hemoglobin in the range of 6-10 g / dl according to Svobodova \& Vyukusova, (1991) and normal nilem hemaglobin levels of $7.8 \mathrm{~g} / \mathrm{dl}$ (Andayani et al, 2014). According to Hastuti (2011), the size of the hemoglobin level in the blood shows the ability to transport oxygen from the gills to the tissues by the blood. Most teleostei fish (hard-boned fish) have the same hemoglobin in erythrocytes as in other vetebrates. Stressful conditions can affect physiological activity and hemoglobin levels in fish. The physiological state of fish blood varies greatly, depending on environmental conditions such as humidity, temperature, and $\mathrm{pH}$ (Adelbert, 2008).

Low levels of fish $\mathrm{Hb}$ according to Bastiawan et al, (2001) cause the metabolic rate to decrease and the resulting energy to be low. This makes the fish weak and has no appetite and is seen sitting at the bottom or hanging under the surface of the water. Amlacher (1970) reported that in addition to bacterial infections, appetite also affects the amount of erythrocytes so that it also affects the hematocrit value and the concentration of hemoglobin in the blood circulation.

\section{Water quality}

Water quality is any change (variable) that can affect management and survival, breeding, growth or fish production (Boyd, 1982). Water quality analyzes carried out included temperature, $\mathrm{pH}, \mathrm{DO}$ and $\mathrm{NH} 3$. The results of water quality analysis during the study period were carried out three times namely the beginning, middle and end can be seen in the following Tables 4.12, 4.13 and 4.14 .

Table 4.18 Water Quality Data during the observation period 
Vol. 5, No. 01; 2020

ISSN: $2456-8643$

\begin{tabular}{|c|c|c|c|c|}
\hline Treatment & \multicolumn{4}{|c|}{ Parameter } \\
\hline & $\begin{array}{l}\text { Suhu } \\
\left({ }^{\mathrm{O} C}\right)\end{array}$ & $\mathrm{pH}$ & $\begin{array}{c}\mathrm{DO} \\
(\mathrm{mg} / \mathrm{L})\end{array}$ & $\begin{array}{c}\mathrm{NH}_{3} \\
(\mathrm{mg} / \mathrm{L})\end{array}$ \\
\hline \multirow{2}{*}{ A } & $26.5-26.6$ & $6.7-7.0$ & $6.7-6.9$ & \multirow{2}{*}{0.0} \\
\hline & $26.6-26.7$ & $6.7-7.0$ & $6.7-6.9$ & \\
\hline \multirow{2}{*}{ B } & $26.6-26.8$ & $6.7-6.9$ & $6.5-6.6$ & \multirow{2}{*}{0.0} \\
\hline & $26.7-26.8$ & $6.7-6.8$ & $6.5-6.6$ & \\
\hline \multirow[b]{2}{*}{$\mathrm{C}$} & $26.7-26.8$ & $6.7-6.99$ & $6.6-6.9$ & \multirow{2}{*}{0.05} \\
\hline & 26.7 & 6.7-6.99 & $6.5-6.9$ & \\
\hline \multirow{2}{*}{ D } & $26.7-26.9$ & $6.8-7.0$ & $6.5-6.6$ & \multirow{2}{*}{0.0} \\
\hline & 26.7 & $6.8-7.0$ & $6.5-6.7$ & \\
\hline \multirow{2}{*}{ E } & $26.6-26.7$ & $6.8-6.99$ & $6.5-6.6$ & \multirow{2}{*}{0.05} \\
\hline & $26.6-26.7$ & 6.8-6.99 & 6.5 & \\
\hline \multirow{2}{*}{$\mathrm{K} 1$} & 26.8 & 6.9 & 6.4 & \multirow{2}{*}{0.0} \\
\hline & 26.9 & 6.8 & 6.4 & \\
\hline \multirow{2}{*}{$\mathrm{K} 2$} & 26.9 & 6.7 & 6.8 & \multirow{2}{*}{0.0} \\
\hline & 26.9 & 6.8 & 6.9 & \\
\hline
\end{tabular}

Note: the first line is the initial temperature, the second line is the temperature at the end of the observation

Table 4.2 in each analysis shows different results. Explanation of each water quality parameter is as follows:

\section{Temperature}

Temperature is one of the important factors in fish farming activities. This is related to the nature of fish which are cold-blooded animals ie their body temperature is influenced by the ambient temperature. When the ambient temperature is high the body temperature of the fish is also high so that the metabolism of the body of the fish is fast and vice versa at low temperatures the metabolism of the fish is also low. This affects the appetite of fish which in turn will affect the growth of fish and ultimately affect production. The temperature value obtained during this study was $26-28.50 \mathrm{C}$. The temperature is still suitable for fish life including catfish. The optimum temperature range for fish life is 25-320C (Kordi, 2004) inside (Sulfia et al, 2015). Good water temperature for catfish growth ranged from 25-300C (Widodo et al., 2007).

\section{Degree of Acidity (pH)}

The degree of acidity $(\mathrm{pH})$ is an important factor affecting fish life. The $\mathrm{pH}$ value obtained during the study ranged from 5.15-6.5 This value can still be tolerated by catfish because catfish can live in acidic water (<7). This is consistent with the opinion of Widodo et al (2007) which states that catfish can grow normally in waters with a $\mathrm{pH}$ range between 4-8.

\section{Dissolved Oxygen (DO)}

Dissolved oxygen content (DO) during the study ranged from 3.5-7.6 $\mathrm{mg} / \mathrm{L}$, where the dissolved oxygen content during the study was low. Although there was a decrease in dissolved oxygen concentration, it was still above $3 \mathrm{mg} /$ liter until the end of maintenance. Mudjiutami (2000) in (Sulfia et al, 2015) said that under oxygen conditions of less than $3 \mathrm{mg} /$ liter, fish can still use organ labyrinths as breathing apparatus. According to Syafriadiman et al (2005) in 
(Sulfia et al, 2015) the most ideal DO for growth and development of aquatic organisms that are maintained is more than $5 \mathrm{mg} / \mathrm{L}$. Water quality is one of the factors that support the growth and survival of fish. Fish need water for all their needs, both to move, eat, grow and multiply.

\section{Ammonia (NH3)}

Ammonia in culture media is dangerous for fish if it is in high concentrations. Ammonia in the maintenance media comes from fish excretion through gills, alteration of metabolic waste, as well as from the remodeling of the remaining food in maintenance media. Ammonia values produced during the study fluctuated and were in the range of $0.013-0.420 \mathrm{mg} / \mathrm{L}$. This value can still be tolerated by fish. According to Boyd (1990) in (Sulfia et al, 2015), the range of ammonia concentration in fish rearing is $<1 \mathrm{mg} / \mathrm{L}$.

\subsection{Treatment Analysis}

Results 4.1 to 4.5 have described various measurements with parameters of survival, hematocrit, leukocrit, blood plasma and hemoglobin levels and their supporting elements in the form of water quality during observation. In determining the best treatment take the value at the end of the treatment or the 17th day as in table 4.19.

\section{Table 4.19. Recommended Treatment Analysis}

\begin{tabular}{|l|l|c|c|}
\hline No. & Parameter & Best criteria & $\begin{array}{c}\text { Best } \\
\text { treatment }\end{array}$ \\
\hline 1. & $\begin{array}{l}\text { Life } \\
\text { sustainability }\end{array}$ & $\begin{array}{c}\text { The highest } \\
\text { percentage value } \\
\text { is the best }\end{array}$ & $\mathrm{C}$ \\
\hline 2. & Hematocrit & $\begin{array}{c}\text { The highest } \\
\text { percentage value } \\
\text { is the best }\end{array}$ & $\mathrm{D}$ \\
\hline 3. & Leukokrit & $\begin{array}{c}\text { The lowest score } \\
\text { is the best }\end{array}$ & $\mathrm{D}$ \\
\hline 4. & Blood plasma & $\begin{array}{c}\text { The highest score } \\
\text { is the best }\end{array}$ & $\mathrm{A}$ \\
\hline 5. & Hemoglobin & $\begin{array}{c}\text { The highest score } \\
\text { is the best }\end{array}$ & $\mathrm{B}$ \\
\hline
\end{tabular}

Table 4.19 can be seen that the treatment $\mathrm{D}$ has the two best parameters compared to other treatments. Survival parameter even though parameter D is not the best but the value is still in 1 group with treatment C. Parameter

The effective treatment in this study was the treatment of $25 \mathrm{ppm}$ dayak onion extract and 75 ppm turmeric extract because even though life did not pass the best was $83.3 \%$, it was still in one group with $86 \% \mathrm{C}$ treatment. However, when viewed from the smallest leukocyte value and the highest hematocrit value at the end of the study.

\section{CONCLUSION}




\subsection{Conclusion}

From the research carried out it can be concluded as follows:

1. Survival in the treatment ranged from $76.67 \%$ to $86.67 \%$, Hematocrit Value at the end of the observation 17.0 to 20.67 , leukocrit value at the end of the observation 2.67 to 8.67 , the value of blood plasma at the end of the observation was 72.33 to 78.33 and the hemoglobin value at the end of the observation was between 5.33 to 6.27 .

2. Water quality parameters such as Temperature which ranges between (25.2-26.8), $\mathrm{pH}$ ranges between (6.01-6.87), DO which ranges between $(6.10-7.7 \mathrm{mg} / \mathrm{l})$ and ammonia which ranges from $(0-0.05 \mathrm{mg} / \mathrm{l})$ can be used for catfish maintenance because it is still in the normal range.

3. Treatment of catfish infected with Aeromonas hydrophilla bacteria using a variety of natural ingredients turmeric extract (Curcuma domestica) and dayak onion extract (Eleutherine palmifolia) with $25 \mathrm{ppm}$ dayak onion extract and $75 \mathrm{ppm}$ turmeric extract is the best treatment.

\subsection{Suggestion}

Based on the above conclusions, the authors advise:

1. Variations of $25 \mathrm{ppm}$ dayak onion extract (EBD) and $75 \mathrm{ppm}$ turmeric extract (EK) are the recommended dosages.

2. The duration of observation for healing can be extended more than 17 days after treatment.

\section{REFERENCES}

[1] Akbar, Junius. 2017. Effectiveness Test of Dayak (Eleutherine palmifolia) Extract Against Healing of Saprolegenia sp. In Tilapia. Journal of Fisheries and Marine Sciences (Fish Scientiae) Vol. 7 No. December 2, 2017 Pg. 49-56.

[2] Ardiansyah, Dimas (2016) Effect of Giving Dayak Onion (Eleutherine palmifolia L. Merr.) Rough Extracts Against Inhibition of Aeromonas hydrophila Bacteria In Vitro. Thesis, Brawijaya University.

[3] Anderson, D. P. and A.K. Siwicki. 1994. Simplified Assays For Measuring Non-Specific Defense Mechanisms in Fish.

[4] Cowan and Steel's. 1993. Manual For Identification of Medical Bacteria - Third Edition. Cambridge University Press. Cambridge, United Kingdom.

[5] Ministry of Health (Ministry of Health of the Republic of Indonesia), 2001, Inventory of Indonesian Medicinal Plants (I), Volume 2, Ministry of Health \& Social Welfare of the Republic of Indonesia, Jakarta.

[6] Effendi, H. 2003. Water Quality Study. Kanisius. Yogyakarta. Di November 9, 2017 
[7] Faizah, Hana. 2013. The effectiveness of Morinda citrifolia L extract against MAS (Motile Aeromonas Septicemia) attack on sangkuriang catfish (Clarias sp). Thesis of the Faculty of Fisheries at the University of Lambung Mangkurat. Banjarbaru.

[8] Fujaya, Yushinta. 2004. Physiology of Fish; Basic Fisheries Engineering Development. Rineka Cipta. Jakarta.

[9] Galingging, R.Y., 2009, Dayak Onions as a Multifunctional Medicinal Plant, Research and Development News, Central Kalimantan, Volume 15 (3).

[10] Gomez, KA, and Gomez AA. 1983. Statistical Procedure for Agriculture Research. Manila (P); An International Rice Research Institute of Los Banos. 680 p.

[11] Gunawan, Surya. 2009. Catfish Cultivation Tips on Narrow Land. Agromedia Reader. Jakarta.

[12] Hanafiah, K. A., 2005. Design of Theory Experiments and Applications. Sriwijaya University Faculty of Agriculture. Palembang.

[13] Hastuti, Sri and Subandiyono. 2011. Haematological performance of African catfish (Clarias gariepinus) and water quality in the media system with the application of biofiltration ponds. Saintek Journal of Fisheries Vol. 6 No. 2 of 2011 Pages 1 - 5.

[14] Irianto, A. 2005. Pathology of Teleostei Fish. Gadjah Mada University Press. Yogyakarta. Diakas9 November 2017

[15] Januarty, Wiwik. 2012. Bioactive Effectiveness of Guava Guava (Psidium gunjava L) Leaves with Different Doses for Treating MAS (Motile Aeromonas Septicaemia) Disease in Dumbo Catfish (Clarias gariepinus). Thesis Faculty of Fisheries. Lambung Mangkurat University. Banjarbaru.

[16] Karmila. U, Sofyatuddin .K, and Yulvizar .C., 2017. Turmeric Extract (Curcuma domestica) as an Anti-bacterial Aeromonas hydrophila in Pangasius Panginus sp. FKp. (Syiah Kuala University), Banda Aceh.

[17] Percival, Steven L, MV Yates, DW Williams, RM Chalmers, NF Gray. 2014. Microbiolgy Of Waterborne Diseases, Microbiological Aspects and Risks. Second Edition. Elsevier Ltd. London. UK

[18] Rukmini. 2012. Aquatic Biota Cultivation Technology. The work of Putra Darwati. Bandung.

[19] Saanin, Hasanudin. 1984. Taxonomies and Keys to Fish Identification. Bina Cipta, Bogor.

[20] Samsundari. 2006. The use of temulawak extract and turmeric water (Curcuma domestica Val) against Aeromonas hydrophila bacteria in carp (cyprinus carpio). Research institutions. UMM (Muhammadiyah University of Malang). Poor. 
[21] Saragih, SP, H. Syawal and M.Rauwaty. 2016. Total Of Erythrocytes, Haematocrit, And Hemoglobin Changes Of Pangasius Hypophthalmus That Were Immersed In Curcumin Extract And That Were In Infected By Aeromonas Hydrophila. Online Journal of Fisheries and Marine Sciences Student Vol. 3 No. 2. 2016.

[22] Sastrahidayat, Ika Rochdjatun Prof.Dr.Ir. 2016. Diseases in Plants Medicines, Spices and Stimules. UB Pres, Malang.

[23] Satratilofa and Sugihartono, Muhammad. 2018. Eleutherine palmifolia Forest Onion Inhibition Test with different extraction methods on the growth of Aeromonas hydrophila bacteria. Journal of River and Lake Aquaculture Vol. 3 No. 2 of 2018 Pg. 56 - 63.

[24] Simatupang, Nora and Anggraini, Dwi. 2013. Potential of Herbal Plants as Antimicrobial in Sangkuriang Catfish (Clarias sp.). Indonesian Swamp Aquaculture Journal Vol.1 No. 2 of 2013. Pages 216 - 225.

[25] Syambas, Basahudin. 2011. Harvest of Catfish 2.5 Months. Self-help Spreaders. Jakarta.

[26] Syamsudin, 1994. Turmeric (Curcuma domestica) cultivation. Bina Cipta, Bandung 3 (5) 143-146.

[27] Utami, Prapti and DE Puspaningtyas. 2013. The Miracle of Herbs. PT. Library AgroMedia. Jakarta 